\section{Methodological proposal for studying suicide as a complex phenomenon}

\author{
Proposta metodológica para abordagem \\ de suicídio como fenômeno complexo
}

\author{
1 Escola Nacional de Saúde \\ Pública Sergio Arouca, \\ Fundação Oswaldo Cruz, \\ Rio de Janeiro, Brasil. \\ 2 Instituto Fernandes \\ Figueira, Fundação Oswaldo \\ Cruz, Rio de Janeiro, Brasil. \\ Correspondence \\ M. C. S. Minayo \\ Centro Latino-Americano \\ de Estudos sobre Violência \\ e Saúde Joge Careli, \\ Escola Nacional de Saúde \\ Pública Sergio Arouca, \\ Fundação Oswaldo Cruz. \\ Av. Brasil 4036, sala 700 \\ Rio de Janeiro, $R J$ \\ 21040-361, Brasil. \\ cecilia@claves.fiocruz.br
}

\begin{abstract}
The authors present a methodological proposal for studying suicide and suicide attempts from a combined socio-anthropological, epidemiological, and psychosocial perspective. This interdisciplinary and complex research model simultaneously examined individual, socioeconomic, historical/cultural, and population data as few studies have succeeded to date. Considering that the present study was conducted in a specific social reality, the authors created a methodological approach to comprehend the effects of a crisis in an industrial restructuring process in a mining company town in the State of Minas Gerais, Brazil, that was associated with unusually high suicide rates. Since it referred to a small geographic area (with only 100,000 inhabitants), the research is considered an ideal case study. The authors created different strategies to trace the local epidemiological profile, adapted a psychosocial autopsy technique to elucidate suicide cases and a psychosocial harm assessment technique to comprehend suicide attempts, and conducted a local analysis of the socio-cultural context. The methods proposed here (with advantages and limitations) proved productive for elucidating the study hypothesis.
\end{abstract}

Suicide; Suicide Attempted; Methods
Maria Cecília de Souza Minayo 1,2

Fátima Gonçalves Cavalcante 1,2

Edinilsa Ramos de Souza 1,2

\section{Introduction}

The focus of this article is an interdisciplinary methodological discussion, including triangulation, on the phenomenon of suicide. Unlike the study presented here, few studies have simultaneously examined the individual, social, anthropological, and epidemiological aspects of suicide. In general the micro and macro dimensions remain dissociated in polarities that prioritize either the individual or society. However, recent studies have begun to draw correlations between risk factors in different dimensions by examining psychiatric, family, psychosocial, socioeconomic, and demographic data 1,2 .

Suicide is a complex problem determined by the interaction between various factors: the biological contribution, personal history, family history, circumstantial events, religion, socio-cultural environment, and historical and socioeconomic context. These numerous facets suggest both case studies on the role played by victims themselves in their own deaths and descriptions of historical, economic, social, and cultural factors associated with the context of occurrence of self-inflicted death, as well as statistical studies of population data contextualizing the problem within the framework of overall morbidity and mortality, in the group of external causes and specifically among the cases of attempted and completed suicide in the various regions studied. To establish such a 
complex methodology situating individuals retrospectively in their existential moment preceding the suicide act, in the historical and social context of their time, and in the scenario of external causes of death among population groups in the region, State, and country of origin, it was necessary to triangulate various approaches.

Methodological triangulation allows going beyond the more classic approaches to foster dialogue between objective and subjective issues, by integrating theoretical and methodological contributions from different disciplinary fields, correlating trends, structures, actions by subjects, indicators, and micro and macro social factors 3,4 . Thus, to study suicide in a multidimensional and multi-causal way, we link fragments of classical sociology 5 with the psycho-sociological approach 6,7 presenting an analytical synthesis.

We used this approach in an empirical study in the city of Itabira, best known as the birthplace of Brazilian poet laureate Carlos Drummond de Andrade and the mining conglomerate CVRD, in the State of Minas Gerais. The municipality has some 100 thousand inhabitants, and its socioeconomic and cultural life has revolved around the mining industry for more than 60 years. The local suicide rates are historically higher than the Brazilian national average, and in the 1990s they increased, accompanying the industrial restructuring process in the mining company, previously state-owned, but privatized in 1997.

Our research method is illustrative in the sense that it can be applied in various dimensions, amenable to being approached in a relatively small socio-demographic area. The key underlying question was: can the increased suicide rates represent a crisis of socioeconomic and cultural degradation in a concrete social space? This question also constitutes our working hypothesis, leading us to link macro-social dimensions to subjective, medical, and microsocial situations and reasons for explaining the social depression that plagued the municipality and was reflected in its residents.

The theoretical and methodological proposal described here has no parallel in Brazilian or international studies. We approach three dimensions: the macro and micro-social; the populational and collective; and the subjective, using the following for this purpose (1) a socioanthropological approach to the context, (2) an epidemiological morbidity and mortality approach, and (3) a psychosocial study. During the research process we combined qualitative and quantitative strategies.

\section{Theoretical basis for a complex approach to the phenomenon}

When Émile Durkheim published his classic study on suicide 8 , which sociologically explained an individual event that appeared to depend on personal and psychological factors, he not only contributed to legitimizing sociology as an independent discipline, but also provided the conceptual framework that is still relevant for explaining suicide as a way of dissolving social ties, as shown by Nunes 9 in his review of this classic work. In Durkheim's words 8 (p. 18): "Rather than viewing suicide only in terms of private events, isolated from each other and each requiring a separate examination, if we consider the set of suicides committed in a given society over a period of time, we note that this total is not merely the sum of the independent units, but itself constitutes a fact that is new and sui generis, with unity and individuality, eminently social in nature".

The concept of suicide is presented as follows by Durkheim 8 (p. 16): "Suicide is applied to all cases of death resulting directly or indirectly from a positive or negative act of the victim himself, which he knows will produce this result." He differentiates it from the notion of attempt, which is "the act thus defined, but interrupted before resulting in death" 8 (p. 16).

By taking a statistical hypothesis within a positivist approach as his basis, Durkheim elaborated a theory of suicidal acts as social acts, without taking into account the existential meanings of concrete subjects embodied in social life. Douglas 10, a scholar of suicide with a social focus, ascribes importance to the biographical and qualitative approach, a focus developed in the work by Baechler 11 (p. 17), stating that "one can interpret suicide as a response to a situation: all suicides result from the fact that the suicidal individual has let himself get caught in a trap. Suicide can thus be interpreted as a 'strategic' solution by the individual to existential problems." In this sense, it is highly recommendable to combine epidemiological and case-study approaches, methods that allow comparing macro-social and micro-social factors, combining notions such as social action and inter-subjectivity.

While evaluating two centuries of violence in Europe, Chesnais 12 concluded that suicide is universal and impregnated with anthropological, religious, ethnic, cultural, environmental, and individual elements. Suicide rates tend to remain constant over long periods of time and to differ between cultures. A sudden increase in overall or age-specific rates can be 
considered a symptom of abrupt change and social powerlessness. High suicide rates were observed in the 1930s, during the Great Depression; low rates were observed in the 1940s, during World War II, when the concern over preservation of life increased; and since the 1950s a gradual increase has been observed worldwide 13 . These data indicate the relevance of socio-epidemiological research methods.

The choice of a psychological method adapted to a psycho-sociological frame of reference took into account the field of suicidology, in expansion since the late 1950s thanks to Edwin Shneidman, considered the founder of this discipline, and other renowned suicidologists 14 , 15,16. According to Shneidman, in the Western world suicide is a conscious act of self-annihilation, best understood as a multidimensional ill-being in a vulnerable individual, defining a thematic problem to which self-extermination is perceived as the best solution 17. Shneidman, in addition to reviewing the contribution of important authors such as Minous, Alvarez, Durkheim, Karl Meninger, Baecheler, and Aaron, situates the psychological perspective in light of other historical, literary, sociological, and psychiatric approaches 14 .

A recent study by Shneidman 18 linked the testimony by relatives, friends, and professionals who witnessed suicide cases and joined with other suicidologists to develop different explanations on (1) what happened?; (2) why it happened?; and (3) whether self-annihilation could have been avoided. According to the author, the success of psychological autopsies lies not in providing a single type of analysis of cases, but in presenting different perspectives on death and the intention to die. Suicide is one of the most illusive and uncertain of themes, and even when we succeed in reaching a single, harmonious explanation, it can still remain confusing and complex for the survivors.

To treat suicide with a complex methodology, we chose to base our method on theoretical thrusts that contrast with the available theories from the last one hundred years, according to a review by Shneidman 14, or in the last decade according to studies by Lester \& Thomas 15 . The latter emphasize the quality of suicide research from the 1960s and 70s and regret the trend in research from the 1990s, during which time they contend that research was poor and lacking in theorization, with no new themes presented 15 . In the 1960s, the authors continue, research closely scrutinized the details of individuals' social relations, frequently observing interacting styles. Current research highly values standardized questionnaires and distant variables, funneling and narrowing the field of study. Our proposal runs counter to the current trends and agrees with the suggestions by Lestes \& Thomas 15 in the sense of prioritizing the examination of social ties, contexts, and subjectivities, thereby raising new questions.

\section{Explanatory models}

Three explanatory models, treated in their interfaces, were chosen as the basis for our proposal: (1) the sociological model, which treats suicide as a social fact embodied in a historical and cultural context; (2) the psychological model, focusing on subjectivity in the network of intra-inter-trans-personal relations; the (3) the nosological model, which relates suicide to psychopathological alterations in the field of mental disorders, disruptions, or diseases.

The point of departure for the "sociological model" conceived by Durkheim 8 is the idea that suicide is an eminently social event and should be studied according to the rules of the sociological method. Durkheim sees suicide as linked to forces that transcend individuals, using data to show that its increase is inversely proportional to the degree of individuals' integration into society, varying according to cultures: "each people has its own suicide trend" 8 (p. 50). According to the author, suicide rates are constant in a given society, which explains its "normalcy" in human communities. Nevertheless, suicide waves occur, namely abrupt changes in the number of suicides in historical moments involving profound social and economic transformations, affecting both individuals and cultural life.

Plausible questions could be raised concerning the case of Itabira based on the Durkheimian concept of suicide wave, given the increases in the town's suicide and attempted suicide rates in the 1990s. The socio-anthropological study published under the title De Ferro $e$ Flexíveis: Marcas do Estado Empresário e Consequências da Privatização na Subjetividade Operária [Ironclad and Flexible: Characteristics of the Entrepreneurial State and Consequences of Privatization for Workers' Subjectivity] 19 allowed a real and metaphorical reading of the suicide-prone environment in Itabira. The hypothesis of the macro-sociological analysis followed the trail of Durkheim and various other authors such as Chesnais 12, Bourgeois et al. 20, and Ostamo et al. 21. A recent article by the latter 21 showed a major increase in suicide attempts associated with socioeconomic depression during a historical moment similar to the current study (1989-1994), in Helsinki, Finland. 
The "psychological model" proposes to link two distinct but complementary areas: (1) clinical psychology and (2) social psychology. The clinical focus considers psychodynamic 22, cognitivist 23 , existential 24 , and systemic studies 25 integrated into the conceptual frameworks of suicidology $14,15,16,17,18$. The social focus uses the approach of psycho-sociology 6,26, a hybrid reference linking sociological and psychological perspectives, taking discourse analysis into account 7 . The psycho-sociological view favors both the social contextualization of individual suicide stories, enriched by the clinical focus, and allows the formulation of analytical categories to find traits that lend unity to isolated cases.

Three studies 13,22,25 illustrate the abovementioned use of clinical references. Cross et al. 13 illustrate the interpretative wealth of the psychological autopsy in light of the psychodynamic focus, highlighting the Freudian view of suicide as an aggression against an introjected love object; the cognitivist view, which relates suicide to a lack of problem-solving ability in the face of stressful situations; the existentialist view, focusing on the difficulty some individuals experience in lending meaning to their lives; and the focus based on theories of suicidology, as presented by Shneidman 27 in describing degrees of disorder in which persons can become enemies of themselves.

Sampaio 25 conducted experimental clinical investigation with young people who had attempted suicide. This author links the individual, family, and social perspectives, highlighting the young person's and family's points of view and their principal forms of social belonging. The suicide attempt is seen as a triple failure to alter an unsustainable situation (at each of the three levels). In this study 25, we underscore the author's integration of the psychoanalytical and systemic references to shed light on the theme. In the systemic focus, individuals are studied in their relational networks, based on interactive patterns that can favor or hinder each member's individual expression. Individual growth is confronted with the need for cohesion and unity in the family system, which under dysfunctional circumstances can produce suffering and generate suicide attempts or suicides, interpreted as symptoms of the system. Along the psychoanalytical line, we cite the work of Cavalcante \& Minayo 22 , analyzing three psychological autopsies from the research in Itabira, revealing the wealth of discursive clues found in family utterances ant the eloquence of suicide as the final speech act.

Psycho-sociology raises the possibility of simultaneously tracing a macroscopic and mi- croscopic dimension of social reality. In this focus, we seek a simultaneous view of the psychological and the sociological that results in something more than the sum of the parts. The rationality and intentionality of meaning seen in social actions are contrasted with situational, relational, or subjective factors.

The "nosological model" studies suicide as the result of disorders or illnesses associated with organic limits or psychosocial and environmental problems. According to Diekstra 28, suicide appears among the ten most frequent causes of death in individuals of all ages. Ernst et al. 29 emphasize that $90 \%$ of suicidal individuals display a detectable psychiatric disorder in psychological autopsies and that $15 \%$ of the deaths are associated with mood disorders, depression being the most relevant 29,30. The principal risk factors associated with suicide are: male gender, psychiatric problems, family history of suicide, and previous attempts. According to a review by Gunnell \& Frankel 31, $30 \%$ to $47 \%$ of individuals who committed suicide had a history of previous attempts.

Conner et al. 32 , in a comparative study on violent conduct and fatal accidents, concluded that predictive factors for suicide are related to violent behavior in the last year of life, especially among young people and women. Violent individuals are more prone to end their lives than to die of accidents. Agitated depression, serotonin disorders, personality disorders with impulsiveness and aggression, and interpersonal crises become relevant risk factors for suicide. A sub-group of alcohol users also displayed high risk when their behavior was characterized by impulsiveness and aggression. Female alcohol users showed a higher propensity to commit suicide than males.

There is a tendency in the European literature 33 to group "suicide attempts" and "selfmutilating acts without the intention to die" in a single category called "parasuicide", a trend still not incorporated by the international literature. In a review of the English-language literature from the last two decades, Welch 33 concluded that there is little information available on parasuicide; the study methodologies and definitions vary; there are more studies in hospitals, with underreporting of cases that do not involve medical assistance; there is a lack of standardized tabulation of suicide attempts; and there is a lack of research on incidence and use of control groups. Risk factors for parasuicide include: female gender, younger age, single or divorced marital status, unemployment, recent changes in one's life situation, mental disorders, and previous attempts. 


\section{Methodology for approaching suicide as a complex phenomenon}

\section{Socio-anthropological study}

We conducted two distinct but complementary studies; the first anthropological study will not be described in detail here in terms of its methodology, since it has already been published in book form 19. In this investigation, Minayo reconstituted the history of workers at the CVRD mining company, marked by the historical development of the largest iron ore exporting company in the world over the course of the last 60 years. Given that $90 \%$ of Itabira's economy hinges on mining, the study analyzes the characteristics of the entrepreneurial state at the local and national levels and highlights the effects of privatization during the 1990s on workers' subjectivity and the social and political costs of this change for the city. It was precisely this transition marked by industrial restructuring introducing abrupt changes that lead to the central question in this research: can an increase in suicide rates represent a crisis of socioeconomic and cultural degradation in a given social space? This study contains a detailed analysis of relations between the company and the town of Itabira and the economic, social, and political effects for its population based on the current changes, clarifying numerous points in this investigation.

In the second socio-anthropological study, we link the first with epidemiological and psychosocial approaches. The previously cited book 19 provided the tone and thrust for the latter two, so that the fieldwork involved the technique of observing the local context and systematically recording ethnographic information on the theme under study. We sought to understand the weight of a closed culture on work and the family within the traditional pattern of company towns 21 ; the cultural roots marking the construction of Itabira's identity (with peasant and farming/livestock raising origins, a history of pan-mining during the goldmining era, and more recently iron ore mining); and further noting that the town offers educational and work areas and cultural, recreational, and sports attractions beyond work itself and outside the home. Considered jointly, these data help understand the social depression that took the town by assault.

\section{Epidemiological study of morbidity and mortality}

We conducted an epidemiological study of the descriptive type. In two previous studies, Mi- nayo \& Souza produced a temporal analysis of mortality from external causes 34 and mortality from suicide 35 in Brazil in the 1980s and 90s. In a third study 36 , we analyzed suicide among young Brazilians ages 15-24 years in nine metropolitan areas from 1979 to 1998 . The methodology in the current study involved two distinct procedures: (1) an epidemiological analysis of overall morbidity and mortality in Itabira and (2) an epidemiological analysis of suicides in Itabira.

\section{- Epidemiological analysis of overall morbidity and mortality in Itabira}

In order to identify the general causes of death and hospitalization, we studied the group of "violence and accidents" and the subgroup "suicide" according to gender, age bracket, marital status, and schooling; alleged causes of suicide and suicide attempts, and the means used. We analyzed the period from 1990 to 2001 for mortality and the year 2000 for hospitalizations. We obtained the data from the Mortality Information System (Sistema de Informações sobre Mortalidade - SIM) of the Brazilian Ministry of Health, a national system created in 1975 which covers nearly $100 \%$ of deaths in Brazil, and from the Hospital Information System of the Unified National Health System (Sistema de Informações Hospitalares/Sistema Único de Saúde - SIH/SUS) of the Ministry of Health (Ministério da Saúde - MoH), implemented in 1993 with the purpose of reimbursement for hospitalization in public and outsourced hospitals. The latter produces administrative data covering $80 \%$ of hospital care in Brazil.

We based our study of the data on the International Classification of Diseases (ICD-9 37 and ICD-10 38). We calculated the mortality rates from violence and accidents during the period 1990 to 2001, according to the entire set of such causes and the specific subgroups (traffic accidents, homicide, suicide, falls, etc.), based on the resident population as provided by the webpage of the Information and Information Technology Department of the National Health System (Departamento de Informação e Informática do SUS - DATASUS - www. datasus. gov.br), a government source available on the Internet. To situate Itabira vis-à-vis other realities, we analyzed it in comparison to the overall national Brazilian data and those for the State of Minas Gerais and the State capital Belo Horizonte. We calculated the overall mortality rates according to gender and age bracket. 


\section{- Epidemiological analysis of suicides in Itabira}

We conducted a detailed and in-depth epidemiological study of the suicides in order to contextualize the phenomenon. We calculated the proportional mortality and mortality rates for the period from 1990 to 2001 . We investigated the following variables: gender, age, schooling, marital status, birthplace, and types of suicide for the first and last years in the temporal series. We divided the population into the following age brackets: 0 -14 years; 15-24; 25-39; 40-59; and 60 and over. We adopted the Brazilian Classification of Occupations of the Ministry of Labor and Employment, version 199439. We defined gender, schooling, and marital status according to the Procedures Manual of the MoH Mortality Information System (2001) 40.

In order to improve the information on suicide, which is known to be underreported, we conducted an active data search in the local notary public's office and in the local Military Police Battalion, with reports from 1996 to 2001, the period during which there were records available by gender, age, month of occurrence, occupation, and means used in suicides and suicide attempts. The notary public uses the same death certificate that generates information for the Mortality Information System. As a second source, we used the police reports filed on suicides at the Military Police Battalion. The criterion for including data was that they appear on both the death certificates and police reports. We excluded deaths resulting from other causes or those in which the cause was difficult to elucidate.

We gathered data on morbidity from Injuries and Poisonings from the "2001 Reduced Files” database on Hospital Admissions Authorizations (Autorizações de Internação Hospitalar-AIH), the CD-ROM on Hospital Morbidity in the SUS by place of residence, technical notes (2002) 41. We defined primary diagnosis as the injury leading to hospitalization and the secondary diagnosis as the external cause generating the injury and hospitalization. This was possible because MoH Ruling 146 of November 13,1997 , makes it mandatory to specify the two types of diagnosis 42 . However, we observed insufficient training in adequately filling in these two categories, and there were frequent cases of the two diagnoses being switched. The morbidity study covered Itabira and also Belo Horizonte, Minas Gerais State, and Brazil for the year 2001.

We analyzed suicide attempts according to the variables gender, age, occupation, season, length of hospital stay, and case fatality. We compared the data from the AIH with an active data search in the Military Police Battalion and with the reports on completed suicides. We produced a large volume of data allowing us to support and compare the other levels of socioanthropological and psychosocial analysis.

\section{Psychosocial approach}

In the clinical and psycho-sociological investigation, whose theoretical basis has been described above, we gathered qualitative data over the course of 2003. The study involved: (1) a literature review for drafting a psychosocial interview script; (2) the creation of two semistructured interview scripts, the Psychosocial Autopsy Script, aimed at a retrospective assessment of suicide cases, and the Psychosocial Harm Assessment Script, to gather primary data on suicide attempts; (3) contacts with the Municipal Health Secretariat for an understanding of the local health system, community services, and public agencies that act in cases of suicide or suicide attempts and to define the psychosocial data collection procedure, aimed at selecting and approaching the families with histories of suicides or attempts, for subsequent interviews.

In drafting the interview scripts, we took into account the research tradition using psychological autopsies, but differentiating our method from some approaches such as those of: (a) Cheng et al. 1, who prioritize clinical and nosological data combined with psychiatric or psychosocial risk factors. Although important and original, this approach is based on endless semi-structured scales that fragment the information into variables, diluting the possibility of identifying a subject, a subjectivity, and a socio-cultural facet in their midst; (b) Werlang \& Botega 43 , who base their approach on an indepth literature review and systematic testing of a semi-structured interview for the psychological autopsy, but make the mistake of utilizing an overly "psychologizing" language in most of the questions comprising the interview, thus committing an obvious psychological reductionism; and (c) Arenales et al. 44, who demonstrate how the lack of a clear and welldrafted interview script can lead to poor and inconclusive analyses.

We drafted interview scripts taking the following into account: (1) the possibility of integrating clinical and nosological data within a biographical and socio-cultural context; (2) attention to avoid getting trapped in psychological or sociological reductionism and to value 
spontaneous narratives and culturally contextualized language, values, attitudes, and beliefs, behavior patterns, and social networks; (3) as a consequence, the use of a common language allowing a careful approach to the theme and facilitating the description of the individuals' biographies and social networks. We found two international sources of inspiration in the Guidelines for Identification, Assessment, and Treatment Planning for Suicidality 45, developed by the Suicide Risk Advisory Committee of the Risk Management Foundation, Harvard Medical Institution, and the work of Sampaio 25 , due to his integrated and global vision in his study of suicide. The theoretical contributions of Shneidman 14,17,18,27, father of the psychological autopsy, enriched our use and analysis of the instruments, adapted here for psychosocial purposes.

The psychosocial autopsy and psychosocial harm assessment each contained up to 67 items or questions distributed among the following areas: (1) personal and family identification; (2) social characteristics (profession, living conditions, etc.); (3) family genealogical tree; (4) assessment of the setting for the suicide or suicide attempt (circumstances preceding or following the act); (5) image of the act or attempt within the family (reactions and impressions by the family system and victim); (6) mental state preceding the suicide or attempts (quality of thoughts, feelings, and emotions, changes in conduct and degrees of discernment, mood or perceptional changes, change in worldview, regular or sporadic treatment, psychiatric diagnosis); (7) personal biography (of the individual who committed or attempted suicide): childhood and adolescence, adulthood and old age, family and social milieu, significant problems and contacts, school - school record and its relevance -, work/employment: position in the labor market or loss of employment, institutional relationships: church, trade union, clubs, associations; (8) self-portrait and way of life (self-descriptions, similarities and differences, reactions to adverse situations, routines, and lifestyle changes). The application of the interview scripts differed in the order and form of the questions.

We chose a case selection that would respond to the sensitivity of the health professionals who were mobilized by the issue at the local level. Given that the Family Health Program of the Municipal Health Secretariat had direct access to the community and covered the entire municipality neighbor-by-neighborhood in both the urban and rural areas of Itabira, we preferred to access the families through this program, with the support of communitybased health agents with a firsthand knowledge of the community's reality. As key informants, these community-based health agents described situations to us and assisted us in the selection process. We managed to collect cases of suicide and suicide attempts by gender, age bracket, and means of perpetration.

We also opted to approach the problem in different neighborhoods in the urban area so as to cover the broadest possible territory. We included a rural area with high suicide prevalence. Among the 26 cases of attempted suicide, we interviewed 15 families, and for the 32 completed suicides we interviewed 13 families. To achieve free adherence by the participants, our universe was 2.5 times greater. The principal cause of refusal to participate was the desire not to touch on the issue. We also held open interviews with eight key social actors (health professionals, health council members, community-based health agents, community leaders, and religious leaders), due to their strategically important social activity in the city. We aimed at adequate socio-cultural contextualization of the theme. A total of 28 families and 8 strategic leaders were interviewed.

The interviews were conducted by a psychologist with extensive clinical experience in family practice and qualitative research, after obtaining informed consent and assembling the respective genealogical tree. The interviews were taped with prior authorization. There was only one meeting with the interviewees, lasting a mean of two hours. We opted to hear as many family members as possible both in the psychological autopsies and harm assessment. We felt that the information would be more dynamic and in-depth if it integrated different points of view, which the family and social support system could help guarantee. We conducted the interviews directly in the homes, allowing the construction of an overview of each family's living conditions.

\section{Final remarks}

The current methodology appeared to raise certain apparently irreconcilable contrasts. On the one hand was classical sociology, for which studying the individual is only justified as the greater expression of a collectivity; on the other hand was a clinical psychology that described subjects and their subjectivities in such a unique and original way that it appeared impossible to extract a collective view. It was in this polarity and tension that we dared to de- 
velop this work, with the certainty that each theory and each method considered separately would not combine the elements needed to answer specific research questions. On the contrary, without these respective contributions, the research results would be impoverished.

In this methodological triangulation, we started with an extensive ethnographic study highlighting the relevance of a symbiotic relationship between the town of Itabira and the mining company CVRD. In the midst of the crisis in international and national industrial restructuring with local specificities, suicide appeared as a relevant category for the population and became the object of study and a crosscutting theme in the psycho-socio-epidemioanthropological approach. The triangulation resulting from the formal approach between disciplines and methods made it possible to respond to the study hypotheses. The effort proved fruitful because there was communication between us, with our knowledge and disciplinary limitations, allowing us to give visibility to a highly relevant social problem in its multiple dimensions, casting a relative light on the existing opinions on the subject that prioritize merely the issue of industrial restructuring.

The epidemiological study showed that the suicide rates increased over the 1990s and peaked in the year of privatization, then tended to decrease in the latter part of the decade, which to a certain extent responds to the key question posed at the beginning of the study and cited in this article. There was evidence for an increase in suicide rates accompanying critical moments in the interface between the town and the company, due to the radical structural changes that preceded and followed privatization of the CVRD, with an evident impact on the local economic and cultural life. The subsequent downward trend in the rates could indicate that the population is adapting to the new changes.

In the 13 psychosocial autopsies, we found two cases of former CVRD employees. In one case we observed the effect of work pressure on a person who already had a family history of mental illness, indicating that the causes of suicide are multiple and multifaceted and cannot be attributed to linear causality, which corroborates Shneidman 14 in the sense that suicide is a slippery issue. In the other case, it was possible to understand the rigidity in the construction of a worker's identity: he retired from the company and in his old age chose to invest his lifetime earnings in a mining company, attempting to imitate the grandiosity of CVRD where he had worked. His dream came to nothing, and in a state of severe, deep depression, he committed suicide. His rigid character and an authoritarian upbringing in relation to work and life progression were factors that made his depression fatal by eliminating all meaning from his life.

Despite facing the specific limits of each area, such as underreporting of epidemiological data and the typical distortions of psychosocial autopsies, our methodological triangulation proved highly productive. In our opinion, disciplinary exchanges do not make up for flaws in disciplines or the deficiencies of experts. Still, if researchers are willing to seek the best in each approach in order to study a theme like suicide, it is possible to enrich the interpretations and to complement important information on social and human problems that resist fitting into disciplinary reductionism.

\section{Resumo}

Neste artigo, as autoras apresentam uma proposta metodológica que estuda o suicídio e a tentativa de suicídio do ponto de vista sócio-antropológico, epidemiológico e psicossocial de forma articulada. Tratase de um modelo de investigação complexo e interdisciplinar que examina simultaneamente aspectos individuais, sócio-econômicos, histórico-culturais e populacionais como poucos estudos atualmente têm feito. Como o presente estudo se apoiou numa realidade social concreta, foi feito um desenho metodológico para se compreender os efeitos de uma crise de reestruturação produtiva numa cidade monoindustrial de $\mathrm{Mi}$ nas Gerais, Brasil, e que esteve associada a um cresci-

mento inusitado das taxas de suicídio. Por tratar-se de um espaço geográfico pequeno (cerca de 100 mil habitantes), o estudo nesta localidade revelou-se como um caso ideal. Desenharam-se diferentes estratégias para traçar o perfil epidemiológico local; técnica de autópsia psicossocial para elucidar casos de suicídio; exame psicossocial de danos para esclarecer tentativas; e análise do contexto sócio-cultural local. Os métodos aqui propostos, com limites e vantagens, revelaram-se ricos e esclarecedores das hipóteses traçadas neste estudo.

Suicídio; Tentativa de Suicídio; Métodos 


\section{Contributors}

M. C. S. Minayo was responsible for the article's overall format and first draft. F. G. Cavalcante was responsible for the entire literature review on suicide and the qualitative and field approach. E. R. Souza was in charge of the quantitative methodology and its integration with the qualitative strategies. The discussions on integration of methods and techniques were conducted collectively.

\section{References}

1. Cheng ATA, Chen THH, Chen CC, Jenkins R. Psychosocial and psychiatric risk factors for suicide. Br J Psychiatry 2000; 177:360-5.

2. Qin P, Agerbo E, Mortensen PB. Suicide risk in relation to socioeconomic, demographic, psychiatric, and familial factors: a national registerbased study of all suicides in Denmark, 19811997. Am J Psychiatry 2003; 160:765-72.

3. Minayo MCS, Assis SG, Souza ER. Avaliação por triangulação de métodos: abordagem de programas sociais. Rio de Janeiro: Editora Fiocruz; 2005.

4. Minayo MCS, Cruz Neto O. Triangulación de métodos en la evaluación de programas y servicios de salud. In: Bronfman M, Castro R, editores. Salud, cambio social y política: perspectivas desde América Latina. Cor del Valle: Edamex; 1999. p. 65-80.

5. Minayo MCS. O Desafio do conhecimento: pesquisa qualitativa em saúde. 8a Ed. São Paulo: Editora Hucitec/Rio de Janeiro: ABRASCO; 2004.

6. Rychlak JFA. A suggested principle of complementarity for psychology. Am Psychol 1993; 48:933-42.

7. Schiffrin D. Approaches to discourse. Oxford: Oxford UK \& Cambridge; 1997.

8. Durkheim E. O suicídio: um estudo sociológico. Rio de Janeiro: Jorge Zahar Editor; 1982.

9. Nunes ED. O suicídio - reavaliando um clássico da literatura sociológica do século XIX. Cad Saúde Pública 1998; 14:7-34.

10. Douglas JJ. The social meanings of suicide. Princeton: Princeton University Press; 1970.

11. Baechler J. Les suicides. Paris: Calmann-Lévy; 1975.

12. Chesnais JC. Histoire de la violence. Paris: Éditions Seuil; 1981.

13. Cross TL, Gust-Brey K, Ball PB. A psychological autopsy of the suicide of an academically gifted student: researcher's and parent's perspectives. Gifted Child Quarterly 2000; 46:247-64.

14. Shneidman ES. Comprehending suicide: landmarks in $20^{\text {th }}$ century suicidology. Washington DC: American Psychological Association; 2001.

15. Lester D, Thomas CC. Why people kill themselves: a 2000 summary of research on suicide. Springfield: Charles C. Thomas; 2000.
16. Maris RW, Berman AL, Silverman MM. Comprehensive textbook of suicidology. New York: Guilford Publications; 2000.

17. Sneidman ES. Definition of suicide. New Jersey: Aronson; 1994.

18. Sneidman ES. Autopsy of a suicidal mind. Oxford: Oxford University Press; 2004.

19. Minayo MCS. De ferro e flexíveis: marcas do estado empresário e conseqüências da privatização na subjetividade operária. Rio de Janeiro: Editora Garamond; 2004.

20. Bourgeois M, Facy F, Rouillon F, Verdoux H. Épidémiologie du suicide. Encyclopédie MédicoChirurgicale Psychiatrie 1997; 10:337-97.

21. Ostamo A, Lahelma E, Lönnqvist J. Transitions of employment status among suicide attempters during a severe economic recession. Soc Sci Med 2001; 52:1741-50.

22. Cavalcante FG, Minayo MCS. Organizadores psíquicos e suicídio: retratos de uma autópsia psicossocial. In: Almeida-Prado MCC, organizador. O mosaico da violência. São Paulo: Vetor; 2004. p. 371-431.

23. Rotheram-Borus MJ, Trautman PD, Dopkins SC, Shrout PE. Cognitive style and pleasant activities among female adolescent suicide attempters. J Consult Clin Psychol 1990; 58:554-61.

24. Mello MF. O Suicídio e suas implicações com a psicopatologia: análise qualitativa de seis casos de suicídio racional. Cad Saúde Pública 2000; 16:163-70.

25. Sampaio D. Ninguém morre sozinho: o adolescente e o suicídio. Lisboa: Editorial Caminho; 1991.

26. Bertaux D. Biography and society: the life history approach in the social sciences. Thousand Oaks: Sage Publications; 1981.

27. Shneidman ES. Suicide thoughts and reflections, 1960-1980. Suicide Life Threat Behav 1981; 11:195364.

28. Diekstra RF. The epidemiology of suicide and parasuicide. Acta Psychiatr Scand 1993; 371 Suppl: 9-20.

29. Ernst C, Lalovic A, Lesage A, Seguin M, Tousignant M, Turecki G. Suicídio e ausência de psico- 
patologia em eixo I. Rev Psiquiatr Rio Gd Sul 2004; 6:268-73.

30. Brodsky BS, Oquendo M, Ellis SP, Malone KM, Mann JJ. The relationship of childhood abuse to impulsivity and suicidal behavior in adults with major depression. Am J Psychiatry 2001; 158: 1871-7.

31. Gunnell D, Frankel S. Prevention of suicide: aspirations and evidence. BMJ 1994; 308:1227-33.

32. Conner KR, Cox C, Duberstein PR, Tian L, Nisbet PA, Conwell Y. Violence, alcohol, and completed suicide: a case-control study. Am J Psychiatry 2001; 158:1701-5.

33. Welch SS. A review of the literature on the epidemiology of parasuicide in the general population. Psychiatr Serv 2001; 52:368-75.

34. Minayo MCS, Souza ER, organizadores. Violência sob o olhar da saúde: a infrapolítica da contemporaneidade brasileira. Rio de Janeiro: Editora Fiocruz; 2003.

35. Santana FS, Souza ER, Minayo MCS, Malaquias JV, Reis AC. Evolução temporal da mortalidade por suicídio no Brasil, 1980 a 1999. Boletim Epidemiológico CLAVES 2002; 2:1-7.

36. Souza ER, Minayo MCS, Malaquias JV. Suicide among young people in selected Brazilian State capitals. Cad Saúde Pública 2002; 18:673-83.

37. Organização Mundial da Saúde. Classificação internacional de doenças. 9a revisão. São Paulo: Edusp; 1975.

38. Organização Mundial da Saúde. Classificação estatística de doenças e problemas relacionados à saúde. 10a revisão. São Paulo: Edusp; 1996.
39. Ministério do Trabalho e Emprego. Classificação brasileira de ocupações. Brasília: Ministério do Trabalho e Emprego; 1994.

40. Fundação Nacional de Saúde, Ministério da Saúde. Manual de procedimentos do Sistema de Informações sobre Mortalidade. Brasília: Fundação Nacional de Saúde, Ministério da Saúde; 2001.

41. Ministério da Saúde. Morbidade hospitalar do Sus por local de residência: arquivos reduzidos. http:// tabnet.datasus.gov.br/cgi/sih/mrdeescr.htm (accessed on 16/Apr/2003).

42. Ministério da Saúde. Portaria SAS n. 142. Dispõe sobre o preenchimento de Autorização de Internação Hospitalar - AIH, em casos com quadro compatível com causas externas. Diário Oficial da União 1997; 17 nov.

43. Werlang BG, Botega NJ. A semi-structured interview for psychological autopsy in suicide cases. Rev Bras Psiquiatr 2003; 25:212-9.

44. Arenales L, Arenales NHB, Cruz JP. Autópsia psicológica em adolescente suicida: Relato de caso. Psychatry on Line Brazil 2002; 7(5). http://www. polbr.med.br/arquivo/artigo0502b.htm (accessed on 12/Apr/2005).

45. Jacobs D, Gutheil TG, Harburger J, Delly MJ, Maltsberger JT, Miller MC, et al. Guidelines for identification, assessment, and treatment planning for suicidality. Cambridge: Suicide Risk Advisory Committee of the Risk Management Foundation, Harvard Medical Institutions; 1996.

\section{Submitted on $14 / \mathrm{Feb} / 2005$}

Final version resubmitted 06/Jun/2005

Approved on 12/Aug/2005 